NBER WORKING PAPER SERIES

CAPITAL STRUCTURE EQUILIBRIUM UNDER

INCOMPLETE MARKET CONDITIONS

Lemma W. Senbet

Robert A. Taggart, Jr. *

Working Paper No. 747

NATIONAL BUREAU OF ECONOMIC RESEARCH

1050 Massachusetts Avenue

Cambridge MA 02138

September 1981

* Graduate School of Business, University of Washington-Madison and J.L. Kellogg Graduate School of Management, Northwestern University. This paper was written while the former author was a visiting Associate Professor of Finance at Northwestern. The research reported here is part of the NBER's research program in Financial Markets and Monetary Economics and project on the Changing Role of Debt and Equity Finances in the United States, which is being financed by a grant from the American Council of Life Insurance. Any opinions expressed are those of the authors and not those of the National Bureau of Economic Research. 


\author{
Capital Structure Equilibrium \\ Under Incomplete Market Conditions
}

\begin{abstract}
Most discussions of corporate capital structure have been set in the context of a complete capital market. In this paper we study the determinants of capital structure for the incomplete markets case, where incompleteness manifests itself in the form of divergent borrowing and lending rates. We argue that firms have a natural incentive to tailor their financing choices so as to narrow such divergences. While this implies an optimal capital structure for firms in the aggregate, however, competition will drive out profits, and the capital structure of any individual firm may still be a matter of indifference. Firms' incentive to try to complete the market provides a rationale for corporate finance even in a taxless environment. This incentive may also shed light on such related issues as corporate mergers, the use of complex securities and the role of financial intermediaries.
\end{abstract}

Lemma W. Senbet Graduate School of Business University of Wisconsin Madison, Wisconsin 53706

(608) 263-6907

Robert A. Taggart, Jr. J.L. Kellogg Graduate School of Management Northwestern University Evanston, Illinois 60201

(312) 492-3562 


\section{CAPITAL STRUCTURE EQUILIBRIUM \\ UNDER INCOMPLETE MARKET CONDITIONS}

Discussion of the Modigliani-Miller (MM, 1958) theorem on the irrelevance of corporate capital structure has largely taken place, explicitly or implicitly, in the context of a complete capital market. Either an Arrow-Debreu world is specifically assumed, as in Hirshleifer (1970), or some variation is invoked, which for practical purposes amounts to the same thing. ${ }^{1}$ The crux of MM's own analysis, for example, is the availability to investors of costless "homemade" leverage, which serves as a perfect substitute for corporate leverage. In subsequent generalizations, a similar role is played by assumptions of costless financial intermediation (Stiglitz, 1974) or the "equal access" assumption (Fama, 1978). The key element in each case, however, has been the availability of a perfect substitute for whatever return patterns might be created by corporations' financing decisions, and in this sense it is always the complete markets case that is under consideration.

The case of incomplete capital markets, by contrast, has remained largely unexplored. Indeed, the phrase "incomplete markets" seems to suggest to financial economists a murky region about which little can be said. ${ }^{2}$ Despite the difficulties cited by other scholars, however, we think that analysis of the incomplete markets case can yield some useful insights into the corporate financing process, and that is the primary point of our paper.

The distinguishing feature of an incomplete market is that marginal rates of substitution between current consumption and all conceivable patterns of future returns are not necessarily driven to equality for all 
investors. In that event, though, there is a clear incentive for corporations to tailor their issues of securities so as to eliminate or at least reduce these divergences in marginal rates of substitution, and this incentive provides a positive role for corporate financing decisions. ${ }^{3}$ A given corporation, of course, would not typically possess a unique ability to enhance the degree of spanning in the capital market. Any one corporation faces competition in this activity not only from other corporations but from individual investors and financial intermediaries as well. The Modigliani-Miller theorem may thus be viewed as the special case in which other parties compete in the capital market on an equal footing with corporations. More generally, however, one might expect corporations, either individually or collectively, to exhibit some comparative advantages in financing, even though their ability to profit from such advantages would be circumscribed by competition from other sectors.

We are by no means the first to suggest that the role of corporate finance lies in helping to complete the capital market. A variety of authors, including J. B. Williams (1938), Durand (1959), Litzenberger and Sosin (1977), Sosin (1978), Litzenberger (1980) and Satterthwaite (1980), have previously alluded to the role of corporate securities in enhancing market completeness. However, the equilibrium implications of this role for corporate finance have not been fully pursued. Our paper extends previous work in the area by taking a specific form of market incompleteness and examining in detail the resulting corporate capital structure equilibrium. We employ primarily the case of divergent borrowing and lending rates that has received previous attention in the asset pricing literature and show that if corporations as a whole can 
borrow and lend advantageously relative to individual investors, then an equilibrium results in which corporate capital structure is determinate at the aggregate level but not at the individual firm level. This will be recognized as similar to Miller's (1977) results under conditions of corporate and personal taxes. This similarity is not surprising, in fact, once it is recognized that implicit tax arbitrage restrictions in Miller's model create the same kind of divergences in marginal rates of substitution that occur in an incomplete market. 4

There is also another parallel between our results and Miller's. If Miller's paper is interpreted as reinforcing perfect market results of modern finance theory by establishing a limited MM indifference result even in the presence of taxes, our paper may be seen in much the same vein. Although market incompleteness can dictate a positive role for corporate finance in the aggregate, the same kind of limited MM result may yet hold at the individual firm level, and in this sense we feel that our analysis underscores the robustness of modern finance theory, even under certain incomplete market conditions. This is contrary to the prevailing notion in the literature that market incompleteness per se rationalizes optimal financial behavior at the individual firm level.

Our analysis proceeds from specific to more general cases. In the first two sections, market incompleteness takes the specific form of a divergence between borrowing and lending rates. We present a model of investors' portfolio selection under these conditions in Section I and also analyze investors' preferences for the capital structure decisions of firms. In Section II we analyze the determination of a capital structure equilibrium when firms have a comparative advantage over individual investors in 
borrowing and lending, and we establish a limited MM theorem. We also show that previous results on asset pricing under divergent borrowing and lending rates disappear if firms are allowed to adjust their capital structures. In Section III we argue that the basic results of Section II are more generally applicable and that they shed light on such topics as bankruptcy and mergers, the role of complex financing instruments and financial intermediation.

\section{Equilibrium with Divergent Borrowing and Lending Rates}

A. The Basic Framework

Consider first, for simplicity, a single representative firm and a single-period economy. Each investor in this economy has an initial endowment of cash, $\mathrm{Y}_{1}^{i}$, as well as an initial shareholding, $\bar{\alpha}^{i}$, in the firm. Investors can either consume or save their endowments, and savings take the form of either bond purchases, $\ell^{i}$, or purchases of fractional shares, $\alpha^{i}$, in the value, $s$, of the firm's stock.

Both firms and individuals are assumed to issue riskless promissory notes in the bond market, so that an individual can be either a borrower or lender, depending on whether $\ell^{i}$ is positive or negative. The bond market is incomplete, however, and this incompleteness manifests itself in divergent borrowing and lending rates. The divergences can be rationalized as follows: We could i.magine either that a market-maker extracts a commission from both parties to each transaction or that market participants directly incur such costs as record-keeping and insuring that all contracts are sufficiently collateralized. In either case, we will let $\lambda$ represent this transaction cost, and in general $\lambda$ may 
depend on the size of each participant's transactions. ${ }^{5}$ If we let $R$ represent the gross interest rate on riskless debt that would prevail in a frictionless capital market, then in our model $\mathrm{R}\left[1-\lambda\left(\ell^{i}\right)\right] \ell^{i}$ is the return on bonds for lenders $\left(\ell^{i}>0\right)$, while $-R\left[1+\lambda\left(\ell^{i}\right)\right] \ell^{i}$ is the cost that borrowers $\left(\ell^{i}<0\right)$ must incur on their debt.

Investors may also deal in the market for corporate stock, where purchase of a fractional share, $\alpha^{i}$, of the firm's stock entitles the investor to the same share, $\alpha^{i}$, of the firm's endof-period profits. These profits, $\Pi$, are given by

$$
\Pi=\tilde{\theta} \overline{\mathrm{X}}-\mathrm{R}\left[1+\lambda^{*}(\mathrm{D})\right] \mathrm{D},
$$

where $\tilde{\theta}$ is a random variable with cumulative distribution $F(\tilde{\theta})^{6}$. If we let $E(\tilde{\theta})=1, \overline{\mathrm{X}}$ may be interpreted as the expected operating cash flow associated with the firm's primary activities, as distinguished from financial (i.e. lending or borrowing) activities. D represents the firm's borrowing in the bond market, and as indicated in (1), the firm also faces a transaction cost function $\lambda^{*}$ when dealing in this market. ${ }^{8}$ The firm's debt is assumed to be issued at par, so that $D$ represents both book value and market value.

B. Portfolio Equilibrium

We first analyze a portfolio equilibrium for investors, consisting of market prices $S$ and $R$, and portfolio holdings, $\ell^{i}$ and $\alpha^{i}$, such that both bond and share markets clear and each investor's expected utility is maximized. 9 This portfolio 
equilibrium is predicated upon an exogenous value of $D$ for the firm. A change in the firm's financing decision would presumably result in a new portfolio equilibrium for investors, and this process will be examined in Section I.C.

The investor's choice problem is to maximize the expected utility of present and future consumption. Since future consumption consists of the investor's income from bond and shareholdings, this amounts to choosing optimal values of $\ell^{i}$ and $\alpha^{i}$, and the problem may be written as

$$
\max _{\ell^{i}, \alpha^{i}} E\left(u^{i}\right)=\int u^{i}\left(C_{1}^{i}, C_{2}^{i}(\tilde{\theta})\right) d F(\tilde{\theta}),
$$

where present consumption, $C_{1}^{i}$, is given by

$$
\mathrm{C}_{1}{ }^{i}=\mathrm{Y}_{1}^{i}-e^{i}-\alpha^{i} \mathrm{~F}^{i} \mathrm{~S}
$$

and future consumption, $\mathrm{C}_{2}^{i}$, is given by

$$
\left.\tilde{\mathrm{C}}_{2}{ }^{\mathrm{i}}=\mathrm{R}[1+\lambda(\ell)] \ell^{i}+\alpha^{i} \tilde{\theta} \overline{\mathrm{x}}-\mathrm{R}\left[1+\lambda^{*}(\mathrm{D})\right] \mathrm{D}\right]
$$

for $\ell^{i}<0$, and

$$
\left.\mathrm{C}_{2}^{i}=\mathrm{R}[1-\lambda(\ell)] \ell^{i}+\alpha^{i} \tilde{\tilde{\theta}} \overline{\mathrm{x}}-\mathrm{R}\left[1+\lambda^{*}(\mathrm{D})\right] \mathrm{D}\right]
$$

for $\ell^{i}>0$ (hereafter we drop the tilde on $\theta$ for convenience).

After some rearranging, investors' first order conditions for an optimal portfolio may be written as

$$
\frac{E\left(u_{1}^{i}\right)}{E\left(u_{2}^{i}\right)}=R\left[1+\lambda(\ell)+\ell^{i} \lambda^{\prime}(\ell)\right] \text { if } \ell^{i}<0 \text {, }
$$




$$
\frac{E\left(u_{1}^{i}\right)}{E\left(u_{2}^{i}\right)}=R\left[1-\lambda(\ell)-\ell^{i} \lambda^{\prime}(\ell)\right] \text { if } \ell^{i}>0,
$$

and

$$
\overline{\mathrm{x}}\left(\int \frac{\partial u^{i}}{\frac{\partial C_{2}^{i}}{E\left(u_{1}^{i}\right)}} \theta d F(\theta)\right)-\frac{E\left(u_{2}^{i}\right)}{E\left(u_{1}^{i}\right)} R\left[1+\lambda^{*}(D)\right] D=S,
$$

where

$$
E\left(u_{1}^{i}\right) / E\left(u_{2}^{i}\right)=\int \frac{\partial u^{i}}{\partial C_{1}^{i}} d F(\theta) / \int \frac{\partial u^{i}}{\partial C_{2}^{i}} d F(\theta)
$$

is investor i's marginal rate of substitution between first-period consumption and certain second-period consumption. Conditions (5a) and (5b) indicate that, unlike the familiar complete markets case, divergent borrowing and lending rates prevent these marginal rates of substitution from being driven to equality for all investors.

Condition (6) represents an investor's subjective valuation at the margin of the firm's stock. Because trading in shares is competitive and unrestricted, these subjective marginal valuations are in agreement for all investors. ${ }^{10}$ Nevertheless, because of divergent borrowing and lending rates, investors may not agree on the value of the separate components of the firm's stock.

To see this, rewrite equation (6) as 11 
$\bar{X}\left[\frac{E\left(u_{2}^{i}\right)}{E\left(u_{1}^{i}\right)}+\frac{\operatorname{cov}\left(u_{2}^{i}, \theta\right)}{E\left(u_{1}^{i}\right)}\right]-\frac{E\left(u_{2}^{i}\right)}{E\left(u_{1}^{i}\right)} R\left[1+\lambda^{*}(D)\right] D=S$

The two terms in equation (7) represent the two components of the market value of the firm's stock. The first of these is investors' valuation of the firm's operating cash flows, $\theta \bar{x}$, while the second is their valuation of future interest payments (receipts) on the firms's debt (bondholdings). The sum of these two components must be the same for all investors, but since the marginal rates of substitution, $E\left(u_{2}^{i}\right) / E\left(u_{1}^{i}\right)$, differ across investors, the separate components of (8) must also differ across investors. In particular, since $E\left(u_{2}^{i}\right) / E\left(u_{1}^{i}\right)$ is smaller for borrowers than lenders, according to (5) borrowers must also possess higher $\operatorname{cov}\left(u_{z^{\theta}}^{i}\right) / E\left(u_{1}^{i}\right)$ so as to arrive at the same equity valuation, $s$, as lenders. This in turn leads us to the natural conclusion that borrowing investors are less risk averse at the margin at a portfolio equilibrium. To see this let us look at a slice of the utility function depicted in Figure $I$. Increases in $\theta$ are associated with increases in $C_{2}^{i}$. Also, we know that $\partial u^{i} / \partial C_{2}^{i}$ is decreasing in $\mathrm{C}_{2}^{i}$ for risk averters, so $\operatorname{cov}\left(u_{2}^{i}, \theta\right)<0$. In addition, the more concave is the utility function, the more negative is this covariance, and hence $\operatorname{cov}\left(u_{2}^{i}, \theta\right) / E\left(u_{1}^{i}\right)$ is an index of risk aversion. Indeed, this term can be viewed as a certainty-equivalent adjustment factor, so that the more negative is this term, the lower is the value that an individual places on the random variable $\theta$. 


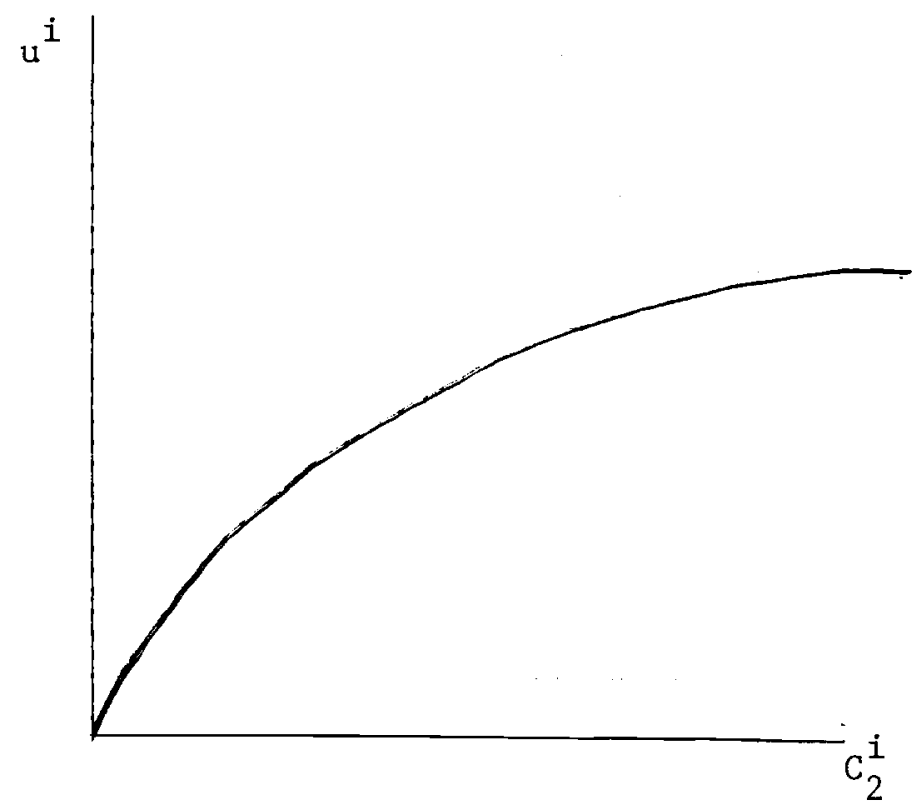

FIGURE I

Investor i's Utility of Second Period Consumption (First Period Consumption Held Constant) 
The index is less negative (or higher) for borrowers as we pointed out earlier, and hence they are less risk averse at the margin. 12

\section{Investor Preferences for the Firm's Capital Structure}

Up to this point investors' portfolio selection has been analyzed, taking the firm's financing decision as given. We could imagine, however, that something like the following process would take place: after an initial portfolio equilibrium had been reached, the firm could poll its shareholders and determine their preferences for any changes in its capital structure. The firm could then alter its capital structure in the desired direction, following which a new portfolio equilibrium would be established with new market prices and possibly a new group of shareholders. The process would repeat itself in exactly the same fashion until the firm could make no further alterations in its capital structure that would unambiguously increase the welfare of its shareholders. At this point a capital structure equilibrium will have been reached.

The problem in analyzing this optimal capital structure is to find a method for investigating investor preferences. In the unanimity literature, two such methods have been employed, and these have been termed the ex ante and ex post modes of unanimity analysis. $^{13}$ In the ex ante analysis the emphasis is on the firm's initial shareholders. When a firm announces a change in its policies, these initial shareholders may choose to sell their 
holdings, and under competitive conditions their preferences will be for those policies that maximize the value of their shares. In the ex post analysis, initial shareholders are constrained to keep their shares (that is, initial and final shareholders are assumed to be the same), and thus their preferences are for those policies creating patterns of return that they most desire, whether or not those policies are value-maximizing. Even if one is ultimately interested in determining value-maximizing financial policies, however, the ex post mode of analysis has the advantage of explicitly displaying those patterns of return that shareholders desire. The ex ante mode by contrast, requires a prediction of how market prices change in response to a change in the firm's policies, and such predictions are difficult in cases where final shareholders are not unanimous in their desires. Since the divergence of borrowing and lending rates causes a lack of unanimity of this kind in our model, we have chosen to follow the ex post mode of analysis. This allows us to identify the different patterns of return that different investors would desire. We can then predict that different firms would choose different capital structures (that is, our representative firm now becomes many firms) so as to satisfy these desires on the part of investors.

We proceed, then, by differentiating a representative investor's expected utility with respect to a change in the firm's debt, evaluating this derivative at a portfolio equilibrium, and constraining $\alpha^{i}=\alpha^{-i}$. For shareholders who are also borrowers $\left(\ell^{i}<0\right)$ this results in ${ }^{* 14}$ 


$$
\frac{d \int u^{i}}{d D} d F(\theta)=E\left(u_{1}^{i}\right)\left(1-\frac{R\left[1+\lambda^{*}(D)+D \lambda^{* i}(D)\right]}{R\left[1+\lambda(\ell)+\ell^{i} \lambda^{\prime}(\ell)\right]}\right) \bar{\alpha}_{i} .
$$

On the other hand, for lenders, we have

$$
\frac{d \int u^{i}}{d D} d F(\theta)=E\left(u_{1}^{i}\right)\left(1-\frac{R\left[1+\lambda^{*}(D)+D \lambda^{*}(D)\right]}{R\left[1-\lambda(\ell)-\ell^{i} \lambda^{\prime}(\ell)\right]}\right) \bar{\alpha}_{i} .
$$

Little can be inferred from these conditions without further assumptions. In general, a given investor's preferences for the capital structure of a firm in which he holds shares depend on whether the investor is borrowing or lending and how much, whether the firm is borrowing and lending and how much, and on any comparative cost advantage or disadvantage that the firm may have in these activities. If the cost functions $\lambda$ and $\lambda^{*}$ have the same form (that is, $\lambda$ and $\lambda^{*}$ have the same sign, as do $\lambda^{\prime}$ and $\lambda^{* \prime}$ ), we would expect from (9.) that lending investors would shun holdings in borrowing firms, and in similar fashion we could infer that borrowing investors would prefer not to hold shares in lending firms. Firms with a variety of capital structures might be expected to evolve, then, in order to serve different clienteles of borrowing and lending investors. ${ }^{15}$ If the cost functions $\lambda^{*}$ were firm-specific one could even derive optimal capital structures for individual firms.

It might be more realistic, as well as more illuminating, however, to suppose that firms as a group possess certain cost characteristics that differ from those of individual investors as 
a group. Borrowing and lending activities are a means of transforming unlevered return streams into alternative streams with different risk and return characteristics, and firms and investors may be seen as competing with one another to perform the desired transformations. In several respects, firms as a group might be expected to have some cost advantages in these activities. There might be economies of scale in record-keeping and collecting or disbursing interest payments, for example. There might also be economies, in monitoring the firms' debt contracts relative to those of individuals. It might be easier to monitor one large borrower, for instance, and then split up this debt into small units through individuals' holdings of shares in the levered firm, rather than to have many individual borrowers, all of whom would need to be monitored. In addition individual investors may be constrained by margin limits on securities debt, whereas firms as a group do not face analogous limitations. For these reasons, we turn now to a more detailed analysis of the case in which $\lambda^{*}$ is the same for all firms while $\lambda$ is the same for all investors, and $\lambda^{*}<\lambda$. To ensure that all firms and investors are identical within their groups, we will also assume that $\lambda^{* \prime}=\lambda^{\prime}=0$.

II. Corporate Leverage as a Means of Completing (Spanning) the Market

A. Capital Structure Equilibrium: A Limited MM Theorem

Suppose, then, that firms can borrow at an effective rate $\mathrm{R}\left(1+\lambda^{*}\right)$ and lend at an effective rate $\mathrm{R}\left(1-\lambda^{*}\right)$, while investors borrow and lend at $R(1+\lambda)$ and $R(1-\lambda)$, and that $\lambda^{*}<\lambda_{0} \quad$ For any given initial capital structures for firms, a portfolio equilibrium 
would be established exactly as in the preceding section.

The capital structure equilibrium, however, would be slightly different. For those individuals who are borrowers, the analogue of equation ( 8 ) would be

$$
\frac{\mathrm{d} \int \mathrm{u}^{i} \mathrm{dF}(\theta)}{\mathrm{dD}}=\mathrm{E}\left(\mathrm{u}_{1}^{i}\right)\left(1-\frac{\mathrm{R}\left(1+\lambda^{*}\right)}{\mathrm{R}(1+\lambda)}\right) \bar{\alpha}_{i}>0 .
$$

Thus, borrowers would prefer that their firms do more borrowing. Similarly, if a firm were a net lender to begin with borrowers preferences for further lending by the firm would be given by

$$
\frac{\mathrm{d} \int \mathrm{u}^{i} \mathrm{dF}(\theta)}{\mathrm{d}(-\mathrm{D})}=\mathrm{E}\left(\mathrm{u}_{1}^{i}\right)\left(\frac{\mathrm{R}\left(1-\lambda^{*}\right)}{\mathrm{R}(1+\lambda)}-1\right) \bar{\alpha}_{i}<0
$$

Thus, borrowers would be actively opposed to the firm doing any lending. For investors who are lenders, the analysis would just be reversed, and the analogue of equation (9) is

$$
\frac{\mathrm{d} \int \mathrm{u}^{i} \mathrm{dF}(\theta)}{\mathrm{dD}}=\mathrm{E}\left(\mathrm{u}_{1}^{\mathrm{i}}\right)\left(1-\frac{\mathrm{R}\left(1+\lambda^{*}\right)}{\mathrm{R}(1-\lambda)}\right) \bar{\alpha}_{i}<0 .
$$

Lenders' preferences for lending by the firm, on the other hand, are given by

$$
\frac{\mathrm{d} \int \mathrm{u}^{\mathrm{i}} \mathrm{dF}(\theta)}{\mathrm{d}(-\mathrm{D})}=\mathrm{E}\left(\mathrm{u}_{1}^{\mathrm{i}}\right)\left(\frac{\mathrm{R}\left(1-\lambda^{*}\right)}{\mathrm{R}(1-\lambda)}-1\right) \bar{\alpha}_{i}>0 .
$$

Thus, lenders are actively opposed to borrowing by firms in which they own shares but are actively in favor of lending by these firms. 
In response to these conflicting desires on the part of investors, some firms would increase their lending while others would increase their borrowing. In fact, since corporate borrowing and lending is a strictly superior substitute for individual borrowing and lending, this process would continue until all borrowing and lending took place among corporations. Investors' portfolios would then consist entirely of corporate shares, with those investors who would formerly have been borrowers holding shares in levered firms and erstwhile lenders holding shares in negatively levered firms.

Once this point had been reached, however, equations (10) and (13) would abruptly change. As soon as all borrowing had been shifted to the corporate sector the marginal rate of substitution between certain first and second period consumption, would change from $R(1+\lambda)$ to $R\left(1+\lambda^{*}\right)$ for all investors who had formerly been borrowing on their own account. Similarly the marginal rate of substitution for formerly lending investors would shift from $\mathrm{R}(1-\lambda)$ to $\mathrm{R}\left(1-\lambda^{*}\right)$.

In this fashion, corporate capital structure adjustments would help to complete the market by driving marginal rates of substitution closer to equality. Investors holding shares in levered firms would still have different marginal rates of substitution and lower degrees of risk aversion at the margin than investors holding shares in negatively levered firms, but these divergences would at least have been narrowed. 
Furthermore, once this change in investors' marginal rates of substitution had taken place, equations (10) and (13) would be identically zero, implying that all investors would be indifferent toward further marginal changes in the capital structures of firms whose shares they held. Capital structure equilibrium in this environment would thus be very much like the equilibrium described by Miller (1977). There would be an optimal amount of corporate debt in the aggregate, and all of this debt would be held by corporations. In the absence of firm-specific costs, however, it would not matter which corporations did the borrowing and lending nor, at the level of the individual firm, how much of it they did. A variety of capital structures covld coexist in equilibrium, and changes in these capital structures would not matter to investors so long as the aggregate level of corporate debt remained unchanged. In this sense we arrive at a limited MM result in which corporate capital structure matters in the aggregate but not at the level of the individual firm. 16

Similar results would emerge for the special case where $\lambda^{*}=0$, so that return streams can be costlessly transformed by corporations. Again corporate borrowing and lending would dominate personal borrowing and lending, and there would be an optimal amount of . corporate debt. In this case, however, capital structure adjustments would be sufficient to drive marginal rates of substitution exactly into equality for all investors. The capital market would be fully spanned even in the face of "unequal access" on the part of individual investors. Furthermore, competition among firms would ensure 
that investors would not be "charged" for this transformation service. Firms would be willing to substitute debt for equity with no differential in the certainty equivalent yields on the two securities, and in equilibrium, therefore, both would have a certainty equivalent yield equal to $R$. In the case considered above by contrast, in which $0<\lambda^{*}<\lambda$, corporate debt would have to bear a differential yield below that of equity in order to give corporations an inducement to issue it.

The question of equilibrium yield differentials on securities has been studied extensively in the asset pricing literature. We now turn to the effect of corporate capital structure adjustments on the conclusions of that literature.

\section{B. A Special Case: Divergent Borrowing and Lending Rates and the} Capital Asset Pricing Model

The problem of divergent borrowing and lending rates has received previous attention in the context of the capital asset pricing model (CAPM). Brennan (1971), for example, has studied equilibrium security pricing for the case where investors have riskless borrowing and lending opportunities but the borrowing rate exceeds the lending rate. Vasicek (1971) and Black (1972) have analyzed the case in which investors have a riskless lending opportunity but no riskless borrowing is allowed. In each of these papers it is demonstrated that the equilibrium expected return on security $j$ has the same linear structure as in the standard CAPM, but the pricing relationship is affected by restrictions on borrowing and lending. 
This effect manifests itself in the intercept and the market price of risk. In each of the three papers as well, the capital market line becomes piecewise linear, with efficient portfolios falling along different segments for borrowing and lending investors. 17

This entire strand of literature, however, takes security supplies as given and thus ignores the capacity of firms to adjust their capital structures in response to divergent borrowing and lending rates at the investor level. If, as in the case considered at the end of Section II.A, firms can borrow and lend at the same rate, then as we have seen, they will have an incentive to rearrange their capital structure until marg nal rates of substitution are equalized for both borrowing and lending investors. In this way, all investors would face the same capital market line and the standard CAPM risk-return relationship would be restored. ${ }^{18}$ This restoration is done at no cost to investors so long as firms are price-takers.

Whereas the literature in corporate finance has tended to focus on the extent to which investors' portfolio operations can undo corporate financing decisions, then, the investments literature has tended to focus on the pricing of fixed supplies of securities. In either case, the positive role that corporate financing decisions can play in completing the market and hence restoring perfect market-type pricing relationships, has been overlooked. 
III. Further Implications of an Incomplete Market Structure for Corporate Finance

Up to this point, market incompleteness has manifested itself in our paper solely in the form of a divergence between riskless borrowing and lending rates. While this case is useful for its simplicity, it is nevertheless somewhat restrictive. In this section, we consider extensions of the fundamental points from preceding sections to more complex situations.

\section{A. Corporate Bankruptcy and Mergers (Spin-offs)}

In the model of Section II, individual investors achieved their preferred portfolio positions by combining equity shares with long and short positions in riskless debt securities. Corporate capital structure adjustments were then a means of augmenting the set of portfolio opportunities that investors could construct on their own account. If we do not restrict corporate and individual borrowing contracts to be free of default risk, risky debt can still play a role in completing the market up to a point. The capacity of any given corporation to issue debt with the desired return attributes, however, depends on the characteristics of its operating cash flow stream.

Consider, for instance, a firm engaged in splitting up its original equity securities into debt and levered equity securities. This is accomplished by the conventional expedient of using the proceeds from the newly issued debt to retire part of the outstanding equity. Accordingly, the total income, $\tilde{Y}$, is partitioned into return streams available to the two classes of securityholders 


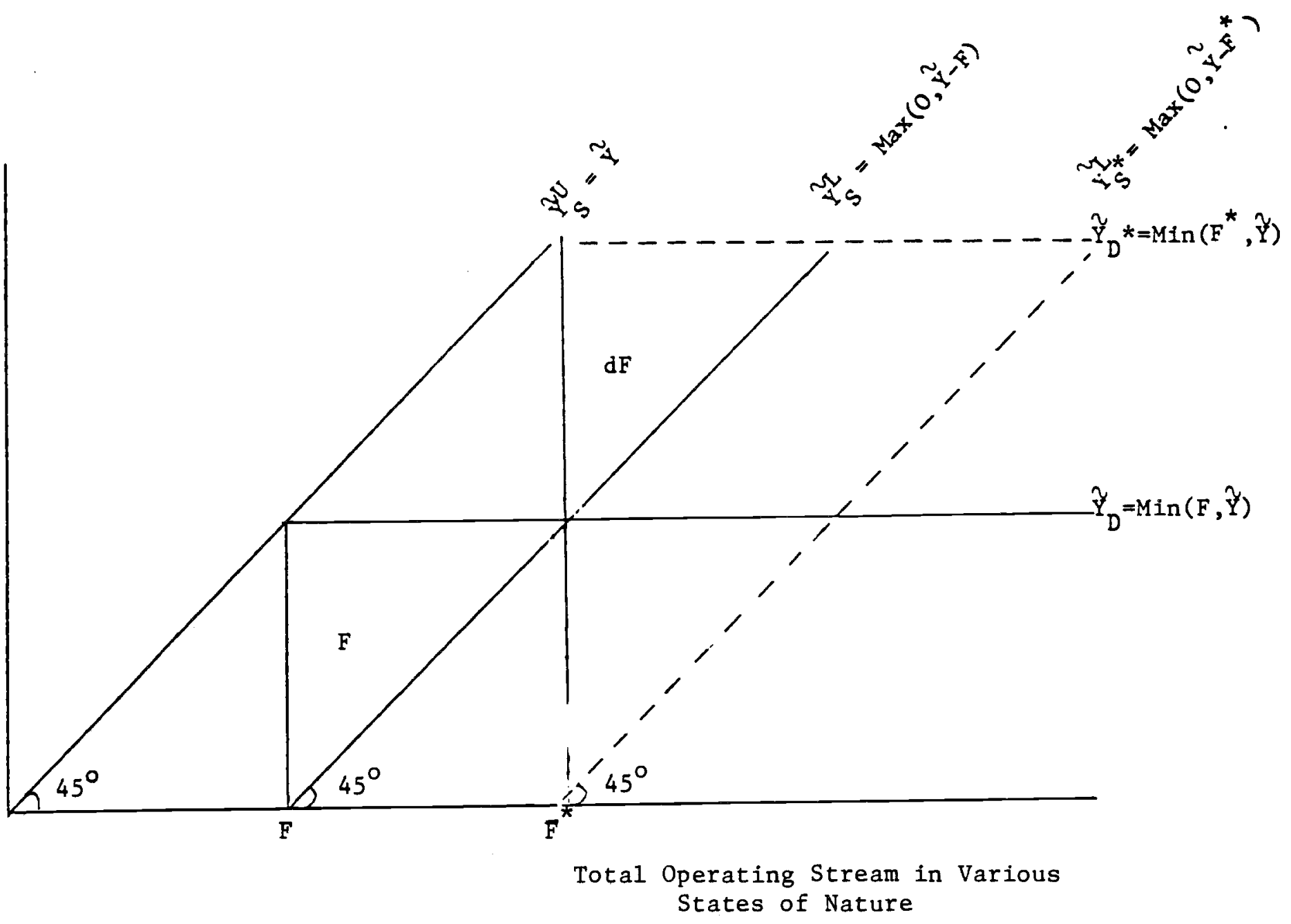

FIGURE II

Partioning of Firm's Operating Income

Stream Through the Use of Debt and Equity Securities 
as depicted in Figure II. The terminal cash flow, $\tilde{Y}$, is measured along the horizontal axis, and the partioned return stream is along the vertical axis. If the promised payment, $F$, on the firm's debt is relatively small, then the debt will be virtually riskless (that is the actual payment will equal the promised payment in almost every state of nature). But as the firm alters its capital structure from the promised payment $F$ to $F^{*}=F+d F$, the corresponding return streams to debtholders and equityholders are altered to $\tilde{\mathrm{Y}}_{\mathrm{D}}$ and $\tilde{\mathrm{Y}}_{\mathrm{S}}^{\mathrm{L}}$, respectively. Indeed, if this process continues, the firm's debt will no longer have its desirable near-riskless propperty, because its return stream approaches that available to unlevered equity. High probabilities of bankruptcy can thus play a negative role in completing the market, because they reduce the available supply of near-riskless debt. From the standpoint of investor welfare, this is much like a bankruptcy cost, but it is fundamentally different from traditional notions of costs associated with formal bankruptcy proceedings either in liquidation or reorganization. This cost arises naturally in the market place through the process of altering the debt security into an "equity-like" security.

If bankruptcy were to introduce a cost of market incompleteness in this sense, it could be mitigated, or even eliminated, through financial synergy. A conglomerate merger is a case in point. $^{19}$ Consider two firms, $A$ and B, having operating cash flow streams that are imperfectly correlated, with equal standard deviations, $\sigma_{A}=\sigma_{B}$. The pre-merger risk-return vector composition 
$\left(\sigma_{A}, Y_{A}\right)+\left(\sigma_{B}, Y_{B}\right)$ is now altered to $\left(\sigma_{A B}, Y_{A B}\right)$ where $\mathrm{Y}_{\mathrm{AB}}=\mathrm{Y}_{\mathrm{A}}+\mathrm{Y}_{\mathrm{B}}$ and $\sigma_{\mathrm{AB}}<\sigma_{\mathrm{A}}=\sigma_{\mathrm{B}}$. The return stream available to debtholders in the merged firm is less "equity-like" than the combination of streams of the unmerged firms. With merger it is possible to support the issuance of additional debt without additional cost of bankruptcy in the sense of market incompleteness. Thus, merger increases the capacity of debt to complete the market. 20 If the process of merging were costless, this activity alone would not affect equilibrium market valuation, but would simply arise as part of the competition among firms to meet investors' desired return patterns. Nonetheless, there would be an optimal economy-wide configuration of firms with various sizes. Whenever departures from this configuration arose, an incentive would exist for certain firms to merge. In this sense, depending upon the underlying investment opportunity sets available to firms, not only mergers but spin-offs would be endogenous in financial equilibrium.

\section{B. A Rationale for Complex Finance}

Although we have focused only on debt and equity securities, a truly complete market may necessitate the existence of other forms of securities to be supplied by firms, such as hybrid securities with option characteristics (e.g. warrants, callable debt, etc.). In a multiperiod environment, a complete market is presumed to have securities that span the available tine-state space. When investors' desires include return patterns across time, 
then securities with multiple periods become relevant. Thus, corporate debt maturity structure, at least in an economy-wide sense, evolves naturally as a means of completing the market. When corporations can costlessly transform their return streams into any securities package, as in the discussion at the end of Section II.A., the certainty-equivalent yield differentials among various classes of securities must be identical in equilibrium. Therefore, the advantages that firms possess in completing the market get "priced out," as long as firms act as price-taking competitors. This is depicted graphically in Figure III. There exists a (certainty-equivalent) yield differential between debt and equity, $-\Theta_{I}$, at which no lender demands corporate debt. At this point the benefit that corporate debt offers to investors in completing the market is outweighed by the yield differential. Stated another way, the negative yield differential on corporate debt is at least as high as the cost associated with financial transformation at the investor level. As long as this personal transformation remains costly, however, there will be some yield differential at which there is a demand for corporate debt, and the demand curve for corporate debt is thus a set of tradeoffs between its benefit in completing the market and its yield disadvantage relative to equity. As the level of corporate debt increases, its marginal benefit in completing the market decreases. Therefore, the demand curve must be upward sloping as investors require a lower yield differential to trade-off against lower marginal benefits. Indeed a zero yield 


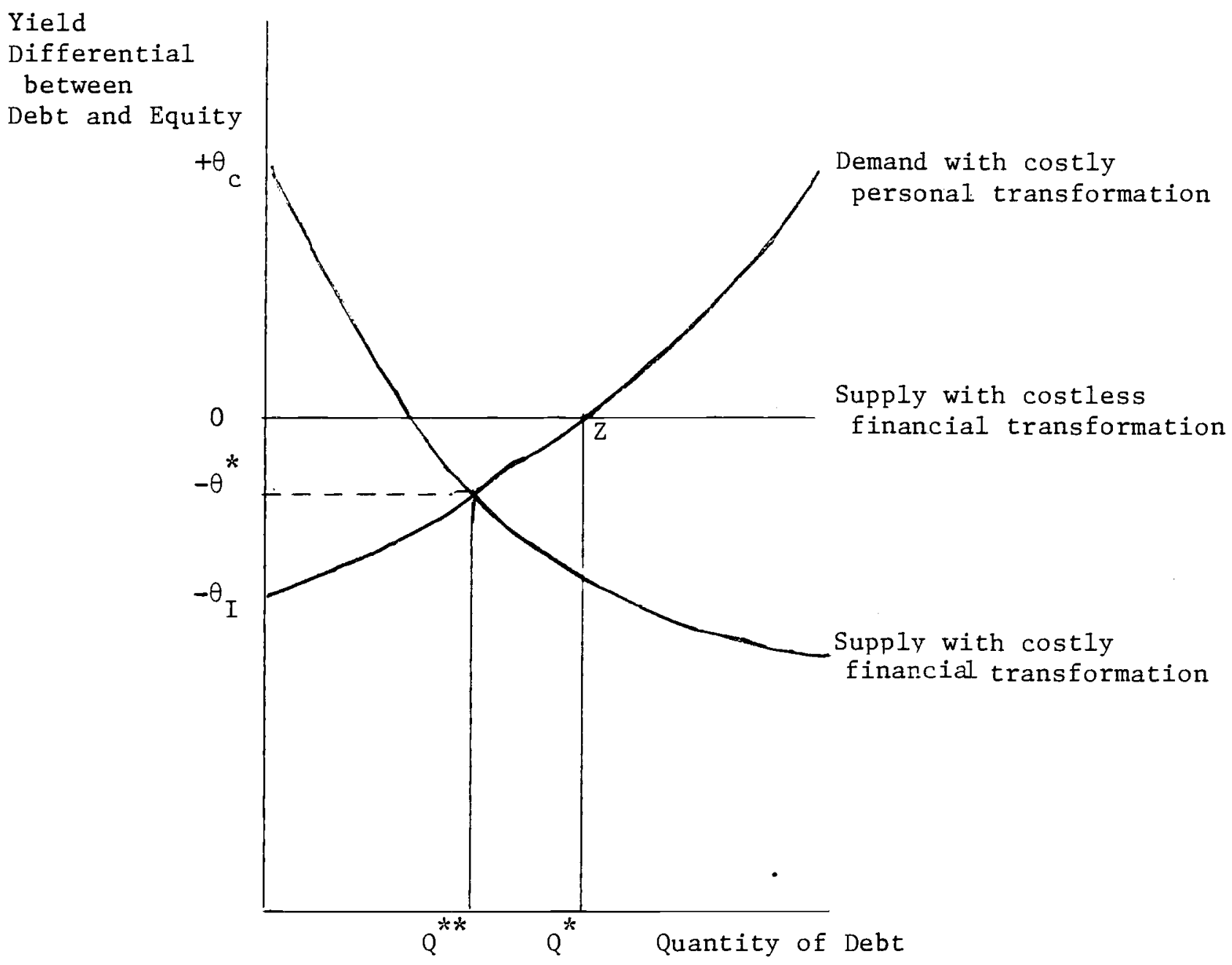

FIGURE III

An Equilibrium Characterization of Financial Tranformation 
differential obtains when the marginal benefits of both debt and equity are driven to zero. This occurs at the point of intersection (Z) between the flat supply curve and the upward sloping demand curves when firms adjust their supply of debt to meet the desired combinations of debt and equity demanded in the aggregate. At this point financial transformation has effectively eliminated the initial effects of an incomplete market at the investor level.

Although this equilibrium is posited in the context of two classes of securities, it can be expanded to multiple classes with a whole range of payoff characteristics. One can envision the development of complex financial securities, such as callable debt and convertible debt, and thus the process of completing the market via corporate financial behavior has the potential for rationalizing observed complex finance even in the absence of agency costs and taxes. $^{21}$ Nonetheless, financial transformation at a particular firm level is of no consequence to its market value unless the transformation itself is costly. Again, this underscores the fact that the limited MM theorem obtains so long as corporate financial policy is costless, irrespective of the degree to which markets are incomplete at the investor level. In particular, the familiar homemade leverage assumption, which is also a disguised assumption underlying Stiglitz (1974) and Fama (1978), is not necessary to this result.

of course, yield differentials occur so long as corporate financial transformation is costly. This is depicted in the downward sloping supply curve in Figure III. The curve is generated by 
the process of firm supply adjustments up to the point where the marginal benefit (cost) of substituting debt for equity is equal to the positive (negative) yield differential between debt and equity. A yield differential can now occur. The differential is positive or negative depending upon the elasticities of the supply and demand curves and their intersection point. Note again that it is not market incompleteness per se which leads to the yield differential. It is the interaction between costs of financial transformation both at the level of firms and investors that leads to the relative value differential among firms of the same risk class. If these transformation costs were firm-specific, there would exist optimal mixes of financial claims not only in an economy-wide sense but also at the level of individual firms. This optimality depends upon relative efficiencies in packaging financial securities across firms and industry groups. More generally, we might expect specialized financial transformers (financial intermediaries) to spring up in such an environment, and it is to this possibility that we now turn.

C. Financial Transformation by Nonfinancial Firms and Financial Institutions.

Up to this point we have considered firms and individual investors as the two groups competing with one another to perform financial transformation activities. Once financial institutions are brought into the picture, this transformation process might 
best be thought of as occurring in two stages.

First, those with expertise in managing real assets organize corporations and partnerships for the purpose of holding and operating these assets. They in turn issue financial claims against these assets in the form of bonds, bank loans, stock and partnership shares. These claims can split up the return stream from the real assets in a variety of ways desired by households. This first element in the economy's financial structure thus consists of the nonfinancial sector's capital structure, broadly construed to consist not only of debt, equity and complex securities, but also the very organization of firms into partnerships and coporations.

The second step in the process of transforming asset characteristics is performed by financial institutions. Although households find it convenient to hold directly many of the financial claims issued by nonfinancial firms, the degree of transformation inherent in these claims may still be insufficient in some respects to match their desired consumption plans. Commercial banks, for example, thus buy debt claims of nonfinancial firms (as well as of households themselves) and enhance their liquidity and divisibility by transforming them into demand and savings deposits; or mutual funds buy stock and bonds and overcome the barriers to diversification implied by security indivisibilities by in turn issuing small-denomination claims on their overall portfolios; or insurance companies hold claims on nonfinancial firms and rearrange their return streams so as to pay off households in the event of death or illness. 
It is important to recognize, however, that the second stage in financial transformation can be performed by nonfinancial firms as well. There is nothing inherent in the institutional arrangement of a financial institution that makes it superior to a nonfinancial firm in performing financial transformation. The theory of financial intermediation is usually thought of as distinct from the theory of corporate finance, but to the extent that both types of institutions help to complete the capital market, they are competing with one another to perform the same function. Apart from distinguishing institutional features such as government regulation, then, we would argue that there is a basic identity between the phenomena that the two theories are attempting to explain.

Another important point to note is that just as the productive process of transforming raw materials into finished goods requires capital and labor resources, so does the process of financial transformation. This has been widely recognized for the case of financial institutions which have long been thought of as having production functions. It has not been explicitly recognized for nonfinancial corporations, however, where the dominance of perfect market models has confined discussion to the case where financial transformation is costless.

The nonfinancial firm can be thought of as operating with two production functions: one that uses capital and labor to produce real goods and services and one that uses capital and labor to transform the characteristics of its real assets into alternative 
financial asset characteristic vectors. From this perspective, the importance of nonfinancial firms' capital structures depends on the characteristics of their financial production functions relative to those of households, financial institutions and one another. If nonfi nancial firms are identical to one another in this respect but possess relative advantages over financial institutions and households, a limited MM theorem will again result. Capital structure will not affect the equilibrium valuations of firms in a given risk class, but the aggregate corporate capital structure will nevertheless be determinate. When viewed in the context of financial production functions, in fact, this limited MM result is analogous to the constant returns to scale case in ordinary microeconomic theory, where industry output alone is determinate, but the size and the output of any one firm are not.

\section{Conclusion}

In order to reconcile returns from the economy's real assets with investors' portfolio needs, the capital market offers a variety of return stream transformations. Nonfinancial firms, financial institutions and even individual investors themselves all compete with one another in the market to perform these desired transformations.

Analysis of the role played by nonfinancial firms in this process has been dominated by the $M$ M theorem, which assumes that financial transformation is costless. Under that assumption individuals and institutions alike are competitive equals in the capital market, and the profits that any one agent might hope to gain through purely financial transformation are inexorably squeezed out. 
In this paper, in contrast to the MM tradition, we have assumed that financial transformation is costly, and thus our analysis of capital structure equilibrium necessarily takes place in an incomplete market setting. Whereas previous discussions have asserted that the incomplete markets case confers monopoly power on individual firms, however, we have retained MM's emphasis on the force of competition. In particular, while we assume that nonfinancial firms as a group may have a comparative advantage over individuals or financial institutions in performing certain transformations, we view these firms as competing with one another on equal terms.

Our principal conclusion is that, rather than being hopelessly intractable, the incomplete markets case can yield useful insights into the function of corporate finance. First, firms' attempts to profit from their comparative advantage will dictate an optimal capital structure for firms in the aggregate. Just as in the complete markets case, however, competition among firms will drive out profits, and in equilibrium the capital structure of any one firm will be a matter of indifference. Nevertheless, these aggregate capital structure adjustments play a positive role in alleviating market incompleteness, and this provides an alternative to the agency theory, and the signalling theory which are the only other currently available rationales for corporate finance in a pre-1913 taxless world. Moreover, firms' incentives to narrow divergences in investors' marginal rates of substitution may also shed light on such related issues as corporate mergers, the use of complex securities and the role of financial intermediaries. 


\section{Footnotes}

1. A particularly strong example of this view may be found in Milne (1974):

It has been said that for the Modigliani-Miller

finance theorems to be true, there must exist perfect markets in assets. Once one has grasped the essential point that a perfect market must involve explicit (or transparently derivable) markets for a given set of returns, these theorems follow easily because the asset model is no more than a thinly-disguised Arrow-Debreu model.

2. Two examples from the literature illustrate the gloomy sentiments surrounding the case of incomplete markets. Baron (1976), for instance, has stated:

If the financing-investment alters the space of available returns in the capital market, the implicit prices will depend on the firm's decisions except under certain special assumptions ... . In such cases where the implicit prices are not independent of the decisions of the firm, the firm is without a guide as to how to work in the best interests of the shareholders since the best interests of shareholders are not in general coincident with changes in the value of the equity of the firm.

And in explaining his reasons for shunning the incomplete markets case, Ross (1977) has said:

Leland, Ekern and Wilson, Radner and others have examined this possibility for activity choice in models with incomplete (marginal) spanning and suggested alternative behavioral rules such as the requirement of stockholder unanimity. This is equivalent, though, to assuming that firms have monopoly power in financial markets, and it is difficult to see a definitive theory emerging from such an inherently game theoretic and strategic situation.

3. In other theories of capital structure, a positive role for corporate finance is provided by such factors as corporate taxes (Modigliani 
and Miller, 1963), bankruptcy costs (Robichek and Myers, 1966;

Kraus and Litzenberger, 1973), agency costs (Jensen and Meckling, 1976), and signalling considerations (Ross, 1977). The theory

presented here offers an alternative to these factors but not necessarily a mutually exclusive one.

4. The relationship between tax arbitrage restrictions and market incompleteness is discussed further in Taggart (1980).

5. The functions $\lambda$ could also be specific to individuals. To simplify the notation we will ignore this complication.

6. Al1 taxes and agency costs are purpcsely ignored in the model in order to focus on the effects of market incompleteness.

7. To simplify the notation, investors are assumed to agree on the distribution of $\theta$. This assumption is not critical to the results.

8. The firm could also choose to be a lender $(D<0)$ in which case its profits would be given by $\Pi=e \bar{x}-R[1-\lambda(D)] D$. We will assume throughout that transaction costs are symmetrical, and thus that there is no reason for either the firm or individual investors to simultaneously engage in borrowing and lending.

9. In arriving at a portfolio optimum, all investors are assumed to act as price-takers.

10. In general, of course, share trading could also be subject to transaction costs, and this could cause divergences in share valuations in much the same fashion that short-selling restrictions cause such divergences in Litzenberger and Sosin (1977). We have chosen, however, to isolate market incompleteness in the bond market so as to highlight its effects. 
In Section III we introduce incompleteness in both markets (albeit in an unspecified form) to rationalize complex finance under incomplete markets.

11. In going from (6) to (7) we have used the following:

and

$$
\int \frac{\partial u^{i}}{\partial c_{2}^{i}} \theta d F(\theta)=E\left(u_{2}^{i} \theta\right)
$$

$$
E\left(u_{2}^{i} \theta\right)=E\left(u_{2}^{i}\right) E(\theta)+\operatorname{cov}\left(u_{2}^{i}, \theta\right)
$$

12. It is interesting to note that $E\left(u_{1}^{i}\right) / E\left(u_{2}^{i}\right)$ can be driven into equality if short sales are unrestricted and if there exists an unlevered riskfree firm among many firms. The expedient of purchases and shortsales of this firm's stock would dominate borrowing and lending for individuals. We shall assume, however, that there is no such a firm.

13. See Baron (1979) and DeAngelo (1981) for surveys of the unanimity literature.

14. Specifically, for

$$
\begin{aligned}
& \frac{\lambda\left(\int \mathrm{u}^{i} \mathrm{dF}(\theta)\right)}{\mathrm{dD}}=\left[\mathrm{E}\left(\mathrm{u}_{2}^{i}\right) \mathrm{R}\left(1+\lambda\left(\ell^{i}\right)+\ell^{i} \lambda^{\prime}\left(\ell^{i}\right)\right)-\mathrm{E}\left(\mathrm{u}_{1}^{i}\right)\right] \frac{\mathrm{d} \ell^{i}}{\mathrm{dD}} \\
& +\left[\bar{x} \int \frac{\partial u^{i}}{\partial C_{2}^{i}} \theta d F(\theta)-E\left(u_{2}^{i}\right) R\left(1+\cdot \lambda^{*}(L)\right) D-E\left(u_{1}^{i}\right) S\right] \frac{d \alpha}{d D} \\
& -\left(E\left(u_{2}^{i}\right) R\left(1+\lambda^{*}(D)+D \lambda^{*}(D)\right)+E\left(u_{1}^{i}\right) \frac{d S}{d D}\right) \alpha_{i} \\
& +E\left(u_{1}^{i}\right)\left(\frac{d S}{d D}+1\right) \bar{\alpha}_{i} \text {. }
\end{aligned}
$$

In the last term of the expression, $+E\left(u_{1}^{i}\right) \bar{\alpha}_{i}$ comes from the fact that when a dollar of additional debt is issued by the firm, the proceeds are used to retire a dollar of equity held by initial shareholders. Substituting (5a) and (6) in the above, and setting $\alpha_{i}=\bar{\alpha}_{i}$ yields (8). 
15. The existence of conflicting investor preferences for firm capital structures provides a rationale for the existence of many firms, even in a single good economy with no diseconomies of scale. Although the production side of the firm is not considered in this paper, it is evident that economies of scale in production would interact with investors'varying desires for leverage to produce an optimal proliferation of capital structures.

16. It is interesting to contrast this with the equilibrium that would result if all the conditions in this section remained the same except $\lambda=\lambda^{\star}$. In this case corporate and personal leverage would be perfect substitutes. There would still be an optimal aggregate level of combined borrowing by firms and individuals, because anything more than this could not be undone without incurring costs. As long as this aggregate level of borrowing were maintained, however, it would not matter whether it was done by firms or individuals. Corporate capital structure would be unimportant not only at the firm level but also at the level of the corporate sector since any increase or reduction in borrowing by firms as a whole could be offset by individual investors.

17. In the models of Vasicek and Black, short sales of the zero beta portfolio take the place of borrowing.

18. Much the same point is made in a different context by Black and Scholes (1974) when they argue that supply responses by firms will tend to eliminate any dividend yield effect from the ordinary CAPM equation, even in the face of personal tax considerations.

19. See Higgins and Schall (1975) for a discussion of conglomerate mergers under the traditional notion of bankruptcy costs. 
20. This is not the whole story, however. Mergers also restrict investors' portfolio flexibility by cementing together the equity streams of the two firms. If good substitutes exist elsewhere in the capital market for the two pre-merger equity streams this creates no problem. Otherwise, there might be a tradeoff between the enhanced ability to issue near-riskless debt and reduced flexibility for equity investors.

21. See Haugen and Senbet (1981) for a discussion of the role of complex securities in resolving agency problems. 


\section{REFERENCES}

K. Arrow, "The Role of Securities in the Optimal Allocation of Risk-Bearing", Review of Economic Studies 31 (1964), pp. 91-96.

D. Baron, "Default Risk and the Modigliani-Miller Theorem: A Synthesis", American Economic Review 66 (1976), pp. 204-12.

, "Investment Policy, Optimality and the Mean-Variance Model", Journal of Finance 34 (1979), pp. 206-232.

F. Black, "Capital Market Equilibrium with Restricted Borrowing", Journal of Business 45 (1972), pp. 444-54.

and M. Scholes, "The Effects of Dividend Yield and Dividend

Policy on Common Stock Prices and Returns", Journal of Financial

Economics 1 (1974), pp. 1-22.

M. Brennan, "Capital Market Equilibrium with Divergent Borrowing and Lending Rates", Journal of Financial and Quantitative Analysis 6 (1971), pp. 1197-1205.

H. DeAngelo, "Competition and Unanimity", American Economic Review 71 (1981), pp. 18-27.

P. Diamond, "The Role of a Stock Market in a General Equilibrium Mode1 with Technological Uncertainty", American Economic Review 57 (1967), pp. 759-76.

D. Durand, "The Cost of Capital, Corporation Finance and the Theory of Investment: Comments", American Economic Review 49 (1959), pp. 639-55.

S. Ekern and R. Wilson, "On the Theory of the Firm in an Economy with Incomplete Markets", Bell Journal of Economics 5 (1974), pp. 171-80

E. Fama, "The Effects of a Firm's Investment and Financing Decisions on the Welfare of its Security Holders", American Economic Review 68 (1978). pp. 272-84.

I. Fisher, The Theory of Interest (London: the MacMillan Company, 1930).

R. Haugen and L. Senbet, "The Insignificance Bankruptcy Costs to the Theory of Optimal Captial Structure", Journal of Finance 33 (1978) pp. 383-93. , "Resolving the Agency Problems of External Capital through Stock Options", Journal of Finance, forthcoming, 1981. 
R. Higgins and L. Schall, "Corporate Bankruptcy and Conglomerate Merger", Journal of Finance 30 (1975), pp. 93-113.

J. Hirshleifer, Investment, Interest and Capital (Englewood Cliffs: Prentice-Hall, Inc., 1970).

M. Jensen and W. Meckling, "Theory of the Firm: Managerial Behavior, Agency Costs and Ownership Structure", Journal of Financial

Economics 3 (1976), pp. 305-60.

H. Kim, W. Lewellen, J. McConnell, "Financial Leverage Clienteles: Theory and Evidence", Journal of Financial Ecomomics 7 (1979) pp. 83-109.

A. Kraus and R. Litzenberger, "A State Preference Model of Optimal Financial Leverage", Journal of Finance 28 (1975), pp. 911-22.

H. Leland, "Production Theory and the Stock Market", Bell Journal of Economics and Management Science 5 (1974), pp. 125-44.

R. Litzenberger, "Debt, Taxes and Incompleteness: A Survey", Unpublished manuscript presented at the 1980 AFA meetings, Denver, Colorado.

R. Litzenberger and H. Sosin, "The Theory of Recapitalizations and the Evidence of Dual Purpose Funds", Journal of Finance 32 (1977), pp. 1433-55.

M. Miller, "Debt and Taxes", Journal of Finance 32 (1977), pp. 261-75.

F. Milne, "Corporate Investment and Finance Theory in Competitive Equilibrium", Economic Record 50 (1974), pp. 511-33.

F. Modigliani and M. Miller, "The Cost of Capital, Corporation Finance, and the Theory of Investment", American Economic Review 48 (1958), pp. 162-97. and "Corporate Income Taxes and the Cost of Capital - A Correction", American Economic Review 53 (1963), pp. 433-43.

N. Nielsen, "The Investment Decision of the Firm Under Uncertainty and the Allocative Efficiency of Capital Markets", Journal of Finance 31 (1976), pp. 587-602.

R. Radner, "A Note on Unanimity of Stockholders Preferences Among Alternative Production Plans: A Reformulation of the Ekern-Wilson Model", Bell Journal of Economics 5 (1974), pp. 181-4.

A. Robichek and S. Myers, "Problems in the Theory of Optimal Capital Structure", Journal of Financial and Quantitative Analysis 1 (1966), pp. $1-35$. 
S. Ross, "The Determination of Financial Structure: the IncentiveSignalling Approach", Bell Journal of Economics 8 (1977), pp. 23-40.

M. Satterthwaite, "On the Scope of Stockholder Unanimity Theorems", International Economic Review, (1981), pp. 119-133.

J. Scott, "A Theory of Optimal Capital Structure," Bell Journal of Economics 7 (1976), pp. 33-54.

H. Sosin, "Neutral Recapitalizations: Predictions and Tests Concerning Valuation and Welfare," Journal of Finance 33 (1978), pp. 1228-34.

J. Stiglitz, "On the Irrelevance of Corporate Financial Policy", American Eocnomic Review 64 (1974), pp. 851-66.

R. Taggart, "Taxes and Corporate Capital Structure in an Incomplete Market", Journal of Finance 35 (1980), pp. 654-59.

0. Vasicek, "Capital Asset Pricing Model with No Riskless Borrowing", unpublished manuscript, Wells Fargo Bank, March 1971.

J.B. Williams, The Theory of Investment Value (Amsterdam: NorthHolland Publising Co., 1938) 